\section{Patient response to laryngeal mask inser- tion after induction of anaesthesia with propofol or thiopentone}

Patrick Scanlon MB BAO BCh FFA RCSI, Michael Carey MB BAO BCh FFA RCSI, Michael Power MB BAO BCh, Fidelma Kirby MB BAO BCh
The response to insertion of the laryngeal mask airway (LMA) following either propofol $2.5 \mathrm{mg} \cdot \mathrm{kg}^{-1}$ or thiopentone 5 $\mathrm{mg} \cdot \mathrm{kg}^{-1}$ was assessed in two groups of patients. The purpose of the study was to ascertain which of these two induction agents provided the better conditions for insertion of the LMA. Anaesthesia was induced by propofol in 35 patients and by thiopentone in 37. Following induction, ventilation was assisted for two minutes using 50\% oxygen and nitrous oxide and $2 \%$ isoflurane, before insertion of the LMA. The presence of gagging, coughing, laryngospasm and movement was noted and graded. Thiopentone was associated with an adverse response in $76 \%$ of patients, compared with propofol in $26 \%(P<0.01)$. Gagging, laryngospasm and head movement were more common using thiopentone $(P<0.01, P<0.05$ and $P<0.05$ respectively) and in $11 \%(P<0.05)$ of the thiopentone group insertion of the LMA was impossible due to inadequate relaxation. We conclude that, using these doses, propofol is superior to thiopentone as an induction agent for insertion of the laryngeal mask airway.

On évalue chez deux groupes de patients la réaction à linsertion du masque laryngé soit après l'administration de propofol 2,5 $\mathrm{mg} \cdot \mathrm{kg}^{-1}$ soit de thiopentone $5 \mathrm{mg} \cdot \mathrm{kg}^{-1}$. L'étude vise à déterminer lequel des deux agents procure les meilleures conditions pour l'insertion du masque. L'anesthésie est induite avec du propofol chez 35 patients et du thiopentone chez 37. Après linduction, la ventilation est assistée avant linsertion du masque pendant deux minutes avec oxygène $50 \%$ dans du protoxyde et isoflurane $2 \%$. La présence de haut-le coeur, toux, laryn-

\section{Key words}

ANAESTHETICS, INTRAVENOUS: propofol, thiopentone; EQUIPMENT: airway, laryngeal mask.

From the Department of Anaesthesia, St. James's Hospital, Dublin, Ireland.

Address correspondence to: Dr. Patrick Scanlon, Department of Anaesthesia, St. James's Hospital, James's Street, Dublin 8, Ireland.

Accepted for publication 10th June, 1993. gospasme et mouvements est enregistrée et cotée. Le thiopentone est associe à au moins un incident chez $76 \%$ des patients, comparativement au propofol avec $26 \%(P<0,01)$. Le hautle-cours, laryngospasme et les mouvements de la tête sont plus fréquents avec le thiopentone $(P<0,01, P<0,05$ et $P<$ 0,05 respectivement). Dans $11 \%$ des cas où le thiopentone est utilisé, linsertion du masque laryngé est rendue impossible par manque de relaxation. Nous concluons qu'avec les doses utilisées, le propofol est supérieur au thiopentone comme agent d'induction pour insertion d'un masque laryngé.

The increasing emphasis on day case anaesthesia has led to the greater use of the laryngeal mask airway (LMA) as an alternative to the face mask and in some cases to tracheal intubation. A depolarising muscle relaxant is not necessary for insertion of the LMA thus avoiding succinylcholine-induced muscle pains which is particularly of benefit when early ambulation is important.

A recent editorial in this journal ${ }^{\prime}$ highlighted the problems that can arise following insertion of the LMA in patients who are not adequately anaesthetised. The choice of induction agent is therefore important. In the setting of day case anaesthesia with its emphasis on early ambulation, the newer induction agent propofol, with its short elimination half-life, would appear to be the induction agent of choice.

The aim of this study was to compare the two most commonly used induction agents, thiopentone and propofol, to see which one better facilitated the insertion of the LMA.

\section{Methods}

The study received previous approval from the Hospital Ethics Committee. Patients undergoing elective minor plastic or orthopaedic surgery were entered into the study. Both in-patients and day cases were chosen to provide a mix of premedicated and non-premedicated patients. Premedication consisted of diazepam $10 \mathrm{mg}$ po $90 \mathrm{~min}$ preoperatively. All gave informed consent and were of 
TABLE 1 Demographic details of patients in the study. Weight and age values expressed as mean $\pm S D$

\begin{tabular}{lcl}
\hline & Propofol & Thiopentone \\
\hline Male & 26 & 23 \\
Female & 9 & 14 \\
Weight (kg) & $72 \pm 14$ & $67 \pm 9$ \\
Age (yr) & $31 \pm 13$ & $33 \pm 10$ \\
\hline
\end{tabular}

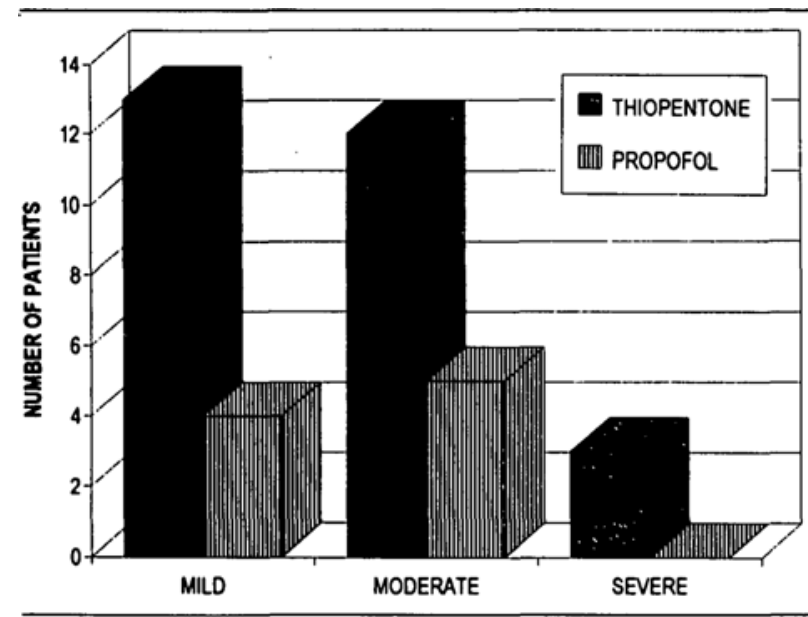

FIGURE Grade of response to laryngeal mask insertion. Only the mild group was significant $(P<0.05)$.

ASA 1 status. Patients with a history of adverse reaction to barbiturates or propofol were excluded from the trial. The patients were randomized to receive either propofol $\left(2.5 \mathrm{mg} \cdot \mathrm{kg}^{-1}\right)$ or thiopentone $\left(5 \mathrm{mg} \cdot \mathrm{kg}^{-1}\right)$. After induction of anaesthesia, ventilation was assisted for two minutes using $50 \%$ oxygen and nitrous oxide and $2 \%$ isoflurane before insertion of the LMA. The LMA's were inserted by the most senior member of the study group, who has considerable experience in this technique.

The patient's response to LMA insertion was noted and included the presence or absence of gagging, coughing, limb and head movement and laryngospasm. The response was graded mild, moderate or severe. A mild response settled within $30 \mathrm{sec}$ without intervention. A moderate response meant the patient required an incremental dose of induction agent. This group included those whose muscle relaxation and mouth opening were inadequate to allow insertion of the LMA. A severe response required succinylcholine $25 \mathrm{mg}$ to allow adequate ventilation and oxygenation. The responses were recorded by an anaesthetist who entered the induction room during the two minutes assisted ventilation phase and who therefore was not aware which induction agent had been used.

Statistical analysis was by Chi-square and Student's $t$ test, the $5 \%$ level of probability $(P<0.05)$ being taken as significant.
TABLE II Patient response to LMA insertion

\begin{tabular}{llll}
\hline & $\begin{array}{l}\text { Propofol } \\
n=35\end{array}$ & $\begin{array}{l}\text { Thiopentone } \\
n=37\end{array}$ & $P$ \\
\hline Overall response & $9(26 \%)$ & $28(76 \%)$ & $<0.01$ \\
Head movement & $4(11 \%)$ & $13(35 \%)$ & $<0.05$ \\
Gag reflex & $7(20 \%)$ & $22(59 \%)$ & $<0.01$ \\
Laryngospasm & $3(9 \%)$ & $11(30 \%)$ & $<0.05$ \\
Inadequate relaxation & $0(0 \%)$ & $4(11 \%)$ & $<0.05$ \\
Cough & $2(6 \%)$ & $7(19 \%)$ & NS \\
Limb movement & $7(20 \%)$ & $13(35 \%)$ & NS \\
\hline
\end{tabular}

TABLE III Incidence of premedication, cigarette smoking and alcohol consumption in both groups

\begin{tabular}{lcll}
\hline & $\begin{array}{l}\text { Propofol } \\
n=35\end{array}$ & $\begin{array}{l}\text { Thiopentone } \\
n=37\end{array}$ & $P$ \\
\hline Premedication & $18(51 \%)$ & $12(32 \%)$ & NS \\
Cigarettes & $8(23 \%)$ & $15(40 \%)$ & NS \\
Alcohol & $17(48 \%)$ & $20(54 \%)$ & NS \\
\hline
\end{tabular}

TABLE IV Influence of premedication, cigarette smoking and alcohol consumption on patients who responded to LMA insertion

\begin{tabular}{llcl}
\hline & $\begin{array}{l}\text { Propofol } \\
n=9\end{array}$ & $\begin{array}{c}\text { Thiopentone } \\
n=28\end{array}$ & $P$ \\
\hline Premedication & $2(22 \%)$ & $9(32 \%)$ & NS \\
Cigarettes & $1(11 \%)$ & $11(39 \%)$ & NS \\
Alcohol & $5(55 \%)$ & $15(53 \%)$ & NS \\
\hline
\end{tabular}

\section{Results}

Seventy-two patients entered the study, 35 in the propofol group and 37 in the thiopentone group. There were no differences between the groups with respect to sex, weight and age (Table I). The Figure shows the grade of response and illustrates that no patient in the propofol group required treatment for laryngospasm. Fewer patients (26\%) in the propofol group responded to LMA insertion than in the thiopentone group (76\%), $P<0.01$ (Table II). There was less head movement (11\%), gagging (20\%), and laryngospasm (9\%) in the propofol than in the thiopentone group (35\% $P<0.05,59 \% P<0.01$, and $30 \%$ $P<0.05$ respectively).

No patient was judged to be inadequately relaxed in the propofol group, and this was less than the $11 \%$ in the thiopentone group $(P<0.05)$.

The incidence of premedication, cigarette smoking and alcohol consumption did not differ between the two groups (Table III) and the influence of these variables in patients who responded is shown in Table IV.

\section{Discussion}

Smooth insertion of a LMA requires attenuation of air- 
way reflexes to avoid sequelae such as gagging, coughing, or laryngospasm. The sequelae can be suppressed by succinylcholine, increased dose of induction agent or narcotics at induction. The problems with these techniques are unpleasant muscle pains following succinylcholine or cardiorespiratory depression and delayed recovery where narcotics or a greater dose of induction agent is given. It is particularly desirable to avoid these in day case anaesthesia.

Therefore, we used an alternative means of attenuating airway reflexes while ensuring rapid recovery and early ambulation. We administered equipotent induction doses ${ }^{2}$ of either propofol or thiopentone but delayed insertion of the LMA until the patients had breathed $2 \%$ isoflurane for two minutes. This time would approximate with the peak brain concentration of both agents, ${ }^{3}$ while the properties of isoflurane ensure rapid uptake and elimination.

Our results show that propofol was the better choice in facilitating LMA insertion. There was less head movement, gagging or laryngospasm in the propofol group and adequate relaxation was better in the propofol group. Previous exposure to smoking and alcohol did not make a difference to these results. Similarly, lack of premedication was not associated with an increase in the number of complications. In similar studies, McKeating et al. found that laryngoscopy was easier when propofol was used, ${ }^{4}$ while Brown et al. found less gagging in response to LMA insertion when propofol was used compared to thiopentone. ${ }^{5}$

In the latter study, all patients who received premedication with diazepam were given fentanyl $1 \mu \mathrm{g} \cdot \mathrm{kg}^{-1}$ at induction. Delayed recovery from anaesthesia with these drugs is an undesirable feature of day case anaesthesia. The greater degree of ventilatory depression with propofol $^{6}$ and its relative analgesic effect compared with thiopentone ${ }^{7}$ may be responsible for the findings presented here and may be sufficient to negate the need for premedication and narcotics before LMA insertion.

The high incidence of adverse responses to LMA insertion following thiopentone suggests that this is an unacceptable induction method if the LMA is used. Adverse responses could be reduced if the dose of thiopentone were increased or if it was supplemented with narcotic. However, this supplementation may be at the cost of increased cardiorespiratory depression and delayed recovery.

The recent editorial on the LMA lists some conditions in which the LMA is unsuitable. 'We conclude from the evidence presented here that one of these, residual intact upper airway reflexes, can be more easily suppressed when propofol $\left(2.5 \mathrm{mg} \cdot \mathrm{kg}^{-1}\right)$ rather than thiopentone $\left(5 \mathrm{mg} \cdot \mathrm{kg}^{-1}\right)$ is used as the induction agent and the patient allowed to breathe $50 \%$ oxygen/nitrous oxide and
$2 \%$ isoflurane for two minutes before insertion of the LMA.

\section{References}

1 Fisher JA, Ananthanarayan C, Edelist G. Role of the laryngeal mask in airway management. Can J Anaesth1992; 39: 1-3.

2 Gepts E, Camu F. Pharmacokinetics of intravenous induction agents. In: White PF (Ed.). Bailliere's Clinical Anaesthesiology, London: Bailliere Tindall, 1991; 5: 513-42.

3 Stanski DR, Hudson RJ, Homer TD, Saidman LJ, Meathe E. Pharmacodynamic modeling of thiopental anaesthesia. J Pharmacokinet Biopharm 1984; 12: 223-40.

4 McKeating K, Bali IM, Dundee JW. The effects of thiopentone and propofol on upper airway integrity. Anaesthesia. 1988; 43: 638-40.

5 Brown GW, Patel N, Ellis FR. Comparison of propofol and thiopentone for laryngeal mask insertion. Anaesthesia 1991; 46: 771-2.

6 Taylor MB, Grounds RM, Mulrooney PD, Morgan M. Ventilatory effects of propofol during induction of anaesthesia. Comparison with thiopentone. Anaesthesia 1986; 41: 816-20.

7 Briggs LP, Dundee JW, Bahar M, Clarke RSJ. Comparison of the effect of diisopropyl phenol (IU 35868 ) and thiopentone on response to somatic pain. $\mathrm{Br} \mathrm{J}$ Anaesth 1982; 54: 307-11. 